УДК 346.12

DOI https://doi.org/10.32849/2663-5313/2020.7.18

\title{
Сергій Чаплян,
}

аспірант

Науково-дослідного інституту приватного права і підприємнищтва

імені академіка Ф.Г. Бурчака

Начіональної академї̈ правових наук Украӥни

\section{ВИНИКНЕННЯ ЗАСОБІВ ПЛАТЕЖУ ТА ЇХ СПІВВІДНОШЕННЯ ІЗ СУМІЖНИМИ ПРАВОВИМИ ІНСТИТУТАМИ}

У статті розглянуто засоби платежу як правовий інститут, їх виникнення та співвідношення із засобами обміну та грошовими коштами, наведено визначення поняттю «платіж», розглянуто такі альтернативні негрошові засоби платежу як криптовалюти. У публікації підкреслено, що приниипова різниия між обміном та платежем полягає в тому, що при обміні майно передається в якості компенсачії за певне благо, в той час як платежем слід вважати дію, спрямовану на передачу зобов'язаною особою управненій особі певного майна, а не виключно грошових коштів, з метою виконання боргового зобов'язання.

Виходячи із вказаного визначення, запропоновано засобами платежу вважати майно (иінності), в тому числі, але не виключно, грошові кошти, що передаються боржником у зобов'язанні кредитору з метою виконання боргового зобов'язання (погашення боргу). За результатами дослідження окреслено співвідношення обсягів понять «засоби обміну» та «засоби платежу», які можуть частково збігатися, але такий збіг не має наслідком ототожнення вказаних понять, враховуючи відмінності їх змісту, оскільки засоби обміну не завжди приймаються в якості засобів платежу.

Поява засобів обміну та платежу є результатом дії ринкових механізмів, проте із множинності засобів платежу внаслідок дії владного примусу держави виокремлюється група законних засобів платежу, які гарантуються державою до прийняття з метою погашення боргових зобов'язань.

У публікачї також висвітлюється питання можливості віднесення до засобів платежу таких новітніх об'єктів товарно-грошового обороту як криптовалюти. Натепер єдиного підходу до иього правового явища немає, і в багатьох країнах, зокрема й в Україні, криптовалюти засобами платежу не визнаються. В той же час низка крайн на рівні законодавства визнала криптовалюти законними засобами платежу.

Виходячи з правової природи иього явища, зроблено висновок про фактичну належність криптовалют до універсальних засобів платежу, проте, враховуючи не можливість визнання на сучасному етапі криптовалют в якості грошових коштів, відповідні платежі не можуть вважатися грошовими, тому їх доцільно позначати терміном «криптоплатежі».

Ключові слова: платіж, засоби платежу, засоби обміну, гроші, криптовалюти.

Постановка проблеми. Поняття «засоби платежу» широко використовується в наукових джерелах і нормативно-правових актах, проте його визначення нормативно не закріплено, а на рівні наукових розробок єдиного уявлення про зміст цього терміну немає. Те ж саме стосується й поняття «платіж». Відсутність єдиного підходу до вказаних понять створює певну правову невизначеність, що має наслідком різні погляди щодо суті платежів і тих засобів, які можуть використовуватися для їх здійснення.

Аналіз останніх досліджень і публікацій. Вітчизняна правова наука взагалі не досліджує засоби обміну та платежу як цілісні правові інститути окремо від інституту грошей, що природно, враховуючи ї тісний зв'язок, але й штучно обмежує обсяги дослідження, адже інститути засобів обміну, платежу і грошей все ж таки є різними за обсягами та змістом.

Теоретичні підвалини дослідження засобів платежу як окремої правової категорії, відмінної від грошей, закладені фундаментальною роботою Л.А. Лунца «Гроші та грошові зобов'язання у цивільному праві» (1927) [1]. На сучасному етапі теоретичні розробки дослідників здебільшого вичерпуються дослідженням тієї чи іншої категорії об'єктів (грошей, грошових сурогатів, електронних грошей або криптовалют) із констатацією їх приналежності (або неприналежності) до засобів платежу без грунтовного опрацювання питань, в силу яких особли- 
востей чи характеристик той чи інший об’єкт може або не може бути віднесений до засобів платежу.

Метою статті $\epsilon$ визначення ознак платежу, ознак об'єктів, які можуть бути кваліфіковані як засоби платежу, розмежування понять «засоби платежу», «засоби обміну» та «гроші».

Матеріали та методи. Методологічну основу дослідження насамперед склали порівняльно-правовий метод та метод історичного аналізу у поєднанні з іншими методами наукових досліджень (індукції, дедукції, абстракції тощо).

Виклад основного матеріалу. Термін «засоби платежу» часто вживається у поєднанні з терміном «засоби обміну», що зумовлено дослідженням обох понять здебільшого в контексті аналізу походження та суті грошей, які визначаються універсальними засобами обміну та платежу.

Засобом обміну є певне благо, властивістю якого є здатність передаватися іншій особі, і така передача є підставою для одержання взамін іншого блага. Оборотоздатність, тобто здатність передаватися і набуватися, $€$ визначальною ознакою засобу обміну, яка виключає використання у цій якості особистих немайнових благ (хоча час від часу з'являються інтригуючі повідомлення про продаж прізвища чи навіть душі, але 3 юридичної точки зору такі «правочини» $€$ нікчемними).

У множинності засобів обміну окрему нішу займає група об'єктів, що може бути узагальнена терміном «універсальні засоби обміну» - це об’єкти, визнані певною групою або спільнотою як такі, які можуть передаватися в якості компенсації за широке коло інших благ. Здебільшого такі об'єкти мають необмежений строк використання і належать до неспоживаних речей, хоча можуть бути і винятки. Універсальні засоби обміну виникають як наслідок усталеної практики, вони не можуть бути результатом примусу чи владного розпорядження, оскільки у такому випадку матимуть абсолютно іншу природу й інші властивості. Як зазначає Л.А. Лунц, закон не може впливати на появу загального засобу обміну, оскільки не може вказувати, що має бути предметом угод, які вчиняються добровільно [1, с. 30].

Обмін має місце, коли зустрічний рух відчужуваних об'єктів відбувається одночасно. За наявності часового розриву з моменту передання першого об'єкта і до передання другого утворюється боргове зобов'язання, погашення якого є платежем. Тому засіб обміну перетворюється на засіб платежу, коли продавець товару стає кредитором а покупець - боржником за зобов'язанням, що має своїм предметом сплату ціни за раніше переданий товар (виконані роботи, надані послуги) [1, с. 154].

Чимало юридичних та економічних енциклопедичних видань взагалі оминають визначення терміну «платіж», що, на мою думку, $є$ великою прогалиною, оскільки це поняття $€$ надзвичайно важливим для цивільного та господарського обороту, а його доктринальне визначення та тлумачення дозволило б найбільш повно розкрити його зміст, враховуючи, що навіть ті поодинокі дефініції, які зустрічаються у довідковій та науковій літературах, можуть відчутно відрізнятися між собою.

У Сучасному економічному словнику платіж визначається як грошові кошти, які належить сплатити в порядку оплати придбаних товарів, за використані ресурси, за наданий кредит, у вигляді встановлених законом внесків, у формі розрахунків за зобов'язаннями [2]. На мою думку, таке визначення $є$ неточним, оскільки платіж спрямований на виконання (і погашення) не будь-якого, а саме боргового зобов'язання. По-друге, з точки зору морфології слово «платіж» є віддієслівним іменником [3]. Такі іменники, утворені від дієслів, насамперед позначають дії, процеси, стани, явища, натомість позначення ними предметів є похідним (здебільшого друге значення). Таким чином, платіж - це насамперед відповідна дія.

Американський юридичний словник "Black's Law Dictionary" визначає платіж як: 1) виконання зобов'язання шляхом передачі грошей або інших щінних речей, прийнятих при частковому або повному виконанні зобов’язання; 2) гроші або іншу цінну річ, передану на виконання зобов'язання [4, c. 1243].

Енциклопедія Британіка називає платежем виконання зобов'язання зі сплати грошей. Платіж має бути здійснений законними грошима, що часто зазначаються як законний засіб платежу, і боржник не має права вимагати заміни цього засобу на інший. Однак сторони можуть дійти згоди, що платіж може бути здійснений будь-яким іншим способом - векселем, чеком або електронним переказом коштів [5].

Якщо відштовхуватися від семантики слова «платіж», Сучасний тлумачний словник української мови визначає його як виплату грошей за що-небудь придбане, використане. При цьому дієслово «платити», від якого утворено іменник «платіж», тлумачиться таким чином: 1) винагороджувати за виконану роботу, видаючи або віддаючи 
гроші чи щось цінне; 2) відшкодувати вартість одержаного або витраченого, використаного; 3) віддавати кошти, виконуючи певні зобов'язання [6, с. 678].

Тобто, значення слова «платити» передбачає передачу не лише грошей, але і «чогось цінного», тому обмеження платежу передачею лише і виключно грошей буде штучним звуженням змісту цього поняття, залишаючи поза його межами платежі у формі інших цінностей, тобто негрошові платежі, а вони також мають місце, адже заборгованість може погашатися не лише грошима.

Німецький економіст Г.Ф. Кнапп (1842 $1926)$ на питання, коли платіж можна вважати грошовим, відповідає, що в разі, якщо відбувається передача металу на вагу, то має місце так званий пензаторний платіж, тобто платіжна сила визначається через фізичні властивості матеріалу (вага, чистота тощо), але грошей ще немає. Але коли платіж відбувається шляхом передачі таврованих знаків, які мають прокламаторну (тобто визначену державою) силу, саме в такому разі можна говорити про гроші [7, с. 22]. Я не оцінюю справедливість такого підходу, оскільки наведений приклад має завданням виключно продемонструвати визнання провідними економістами існування негрошових платежів.

Отже, принципова різниця між обміном та платежем полягає в тому, що у другому випадку майно передається не як компенсація за певне благо, а саме з метою погашення боргового зобов'язання, яке утворилося між сторонами. На цій підставі С.А. Тертишний виділяє платіжний оборот, коли гроші використовуються для погашення зобов'язань і функціонують саме як засоби платежу. Платіжний оборот може бути як готівковим, так і безготівковим, причому весь безготівковий оборот, на думку С.А. Тертишного, є платіжним, адже передбачає розрив у часі між рухом коштів і рухом товарів, а саме в такому випадку гроші функціонують як засоби платежу [8, с. 10].

Останнє твердження, на мою думку, є дещо поспішним, оскільки не враховує низку грошових операцій, які можуть здійснюватися у безготівковому порядку, але не кваліфікуються як платежі, наприклад безпідставне безготівкове перерахування коштів (у господарській діяльності такі випадки непоодинокі), яке включається до безготівкового обороту, але за своїми ознаками не належить до платежів.

3 урахуванням наведеного, можна визначити платіж як дію, спрямовану на передачу зобов'язаною особою управненій особі певного майна, в тому числі, але не виключно грошових коштів, з метою виконання борго- вого зобов'язання. Друге значення платежу як майна, що передається, вважаю похідним від визначення платежу як дії. Відповідно й засобом платежу є грошові кошти, а також інше майно (цінності), що передаються боржником у зобов'язанні кредитору 3 метою виконання боргового зобов'язання (погашення боргу).

Категорія універсальності засобів платежу (як і щодо засобів обміну) вказує на широко розповсюджене використання багатьма учасниками цивільного та господарського обороту певного об'єкта в якості засобу платежу (незалежно від його офіційного визнання чи невизнання в якості законного засобу платежу). Поєднання в одному об'єкті універсального засобу обміну та платежу утворює особливий об'єкт цивільно-правових і господарсько-правових відносин - гроші. При цьому обсяги понять «засобів обміну» і «платежу» залишаються ширшими за обсяг поняття «гроші».

Безумовно, останні належать і до засобів обміну, і до засобів платежу, але далеко не завжди можуть ототожнюватися 3 ними. Коректність співставлення напряму залежить від змісту, що вкладається у ці поняття, насамперед це стосується поняття «гроші». Таке співставлення $є$ більш важливим у зв'язку з виділенням у множинності засобів платежу окремої групи законних засобів платежу, наділених легальною платіжною силою, яка полягає в тому, що зобов’язання, яке може бути погашено шляхом грошового платежу, може бути погашено шляхом передання законного засобу платежу, і кредитор під загрозою виникнення прострочення (mora creditoris) має прийняти його в якості виконання боргового зобов'язання [1, с. 52-53], за відсутності об'єкта, безпосередньо зумовленого сторонами, в якості юридично рівноцінного замінника боржник може запропонувати законний засіб платежу.

Законні засоби платежу виникають саме внаслідок імперативного розпорядження держави, на відміну від звичайних засобів платежу, які можуть прийматися без будьякої участі держави, наприклад внаслідок домовленості у певній людській спільності на основі звичаю чи «суспільного договору», як у відомому прикладі з саморобною горілкою в радянські (і не тільки в радянські) часи: за відсутності у населення грошей, особливо в сільській місцевості, найбільш ходовим засобом обміну та платежу на рівні побутових цивільних відносин між фізичними особами був самогон - саморобна горілка, яку виготовляли у багатьох домогосподарствах.

Зрозуміло, що в офіційних розрахунках про такий «засіб платежу» не могло бути 
й мови, але між людьми він використовувався досить широко. Російський письменник А. Сенніков в оповіданні «Долина тіней» писав: «Самогон у селі був, $є$ і буде. Він і товар, і засіб платежу, і бальзам від душевних ран, і ліки від всіх тілесних хвороб» [9]. I це не одиничний приклад. Як зазначає Д. Везерфорд, «сигарети, шоколад і жувальна гумка заповнили монетарні діри по всій Свропі вкінці Другої світової війни» [10, с. 30].

Визначення кола законних засобів платежу, які за термінологією Л.А. Лунца виступають «універсальним сурогатом виконання майнових зобов'язань» [1, с. 31] і «граничними і примусовими засобами виконання зобов'язань» [1, с. 31], відбувається через встановлення гарантування на рівні державного примусу, в силу припису закону. При цьому «один лише факт випуску в оборот певних грошових знаків державою не створює законного засобу платежу» [1, с. 279], оскільки «будь-який законний засіб платежу $€$ грошима, але не всі гроші - законні засоби платежу» [1, с. 287].

Так, в Англії з 1663 по 1813 рік карбувалася золота монета - гінея. І хоча вона карбувалася урядом і належала до грошей, як засіб платежу вона приймалася у перерахунку на шилінги, причому курс з часом змінювався: якщо на початку «вартість» монети прирівнювалася до 21 шилінга, то пізніше вона досягала навіть 30 шилінгів [11, с. 41]. При цьому заборгованість виражалася і погашалася у шилінгах і фунтах стерлінгів.

Зв'язок і відмінності між засобами обміну та платежу Л.А. Лунц демонстрував на таких прикладах: 1) законний засіб платежу стає засобом обміну, коли, наприклад, держава випускає паперові знаки, визначаючи, що 3 їх допомогою можна погашати існуючі борги; 2) засіб обміну стає законним засобом платежу, коли, наприклад, держава починає чеканити монети із золота, яке і до цього в обороті використовувалося як засіб обміну [1, с. 31]. Але і в першому, і в другому прикладі чітко простежується те, що законний засіб платежу виникає внаслідок вольової дії держави (суверена).

Поняття «засоби обміну» $\mathrm{i}$ «засоби платежу» в сучасних умовах можуть збігатися за обсягом, проте цей збіг не має логічного характеру і не випливає із суті самих цих явищ, які є різними за своїм змістом [1, с. 31]. Продовжуючи цю думку, Н.М. Розанова зазначає, що засіб платежу обов'язково одночасно є засобом обміну, але засіб обміну далеко не завжди буде функціонувати в якості засобу платежу [12, с. 33].

В українському законодавстві категорії «засіб платежу», «платіжний засіб» і «закон- ний платіжний засіб» є усталеними і широко вживаними. Зокрема, згідно зі ст. 192 Цивільного кодексу України (далі - ЦК України) [13] законним платіжним засобом, обов'язковим до приймання за номінальною вартістю на всій території України, є грошова одиниця України - гривня. Стаття 3 Закону України «Про платіжні системи та переказ коштів в Україні» [14] визначає, що гривня як грошова одиниця України є єдиним законним платіжним засобом в Україні. В аналогічному розумінні термін «платіжний засіб» наводиться у ст. 35 Закону України «Про Національний банк України» [15]. Як зазначається в листі Національного банку України від 07.06.2013 № 25-112/6750 [16], платіжний засіб існує у формі грошової одиниці.

Термін «засіб платежу» у законодавстві України не визначений, і це офіційно визнано Національним банком України в листі від 07.06.2013 № 25-112/6750 [16], але він активно використовується у нормативноправових актах. Так, згідно зі ст. 15 Закону України «Про платіжні системи та переказ коштів в Україні» [14] електронні гроші приймаються «як засіб платежу». В науковій літературі обидва терміни (платіжний засіб i засіб платежу) часто розглядаються як тотожні, тобто такі, що позначають одне і те ж явище - певний об'єкт, який використовується для оплати боргових зобов'язань.

У контексті піднятого питання варто сказати кілька слів про такий новітній засіб платежу, як криптовалюти (або криптоактиви, як їх все частіше називають). Якщо електронні гроші в Україні отримали нормативне закріплення і визнані засобами платежу, то криптовалюти ще залишаються у невизначеному становищі, оскільки законом вони не заборонені, але й правового регулювання їх емісії та обігу досі немає, при цьому ставлення правоохоронних органів до криптовалют навряд чи можна назвати позитивним.

У різних країнах правове регулювання криптовалют істотно відрізняється, варіюючись від прямої заборони, визнання криптовалюти товаром до прийняття іï в якості засобу платежу. Постають закономірні питання, наскільки обгрунтовано визначати криптовалюту як засіб платежу, і чи є підстави вважати перерахування криптовалюти платежем? До цих питань існують різні підходи. Так, у жовтні 2012 року Європейський центральний банк (European Central Bank), використовуючи термін «віртуальна валюта», визначав її як тип нерегульованих цифрових грошей, який видається і зазвичай контролюється його розробниками, використовується і приймається серед членів певного віртуального співтовариства [17]. Проте вже 
у жовтні 2016 року ЄЦП дійшов протилежного висновку, що віртуальні валюти не є ані грошима, ані валютою, а є, скоріше, засобом обміну, але не платежу [18].

Натомість Європейський суд справедливості (European Court of Justice), використовуючи аналогічну термінологію, дійшов абсолютно протилежного висновку у своєму рішенні від 22 жовтня 2015 року у справі Хедквіст проти Швеції, зазначаючи, що криптовалюта Bitcoin є договірним платіжним засобом [19], і в подальшому він був визнаний таким у багатьох країнах.

Так, у лютому 2018 року Федеральне міністерство фінансів Федеративної Республіки Німеччина роз'яснило, що віртуальні валюти (криптовалюти, як, наприклад, Bitcoin) прирівнюються до законних засобів платежу настільки, наскільки вони були прийняті сторонами угоди як альтернативні договірні і прямі засоби оплати, що не слугують жодній іншій цілі, крім використання в якості засобу платежу [20].

Уряд Японії (Японської Держави) у 2017 році схвалив зміни до Закону «Про банківську діяльність» і офіційно визнав Bitcoin законним засобом платежу [21]. Уряд сусідньої з Україною Республіки Білорусь не пішов так далеко, щоб визнати криптовалюту законним засобом платежу, але визнав iii універсальним засобом обміну [22].

Чимало зарубіжних країн знаходить інші категорії для визначення криптовалюти, причому в цьому випадку проблема визначення полягає не стільки у криптовалюті, скільки у ставленні до неї того чи іншого регулятора.

Якщо проаналізувати зміст, властивості i історію виникнення та стрімкого розвитку криптовалют, стає очевидним, що традиційні криптовалюти не здатні жодним іншим чином задовольняти споживчий попит, аніж виступаючи в якості засобів обміну та платежу, для жодного іншого використання вони не придатні.

Більше того, вони і задумані були саме як альтернативні офіційним грошам засоби обміну та платежу (або навіть як альтернативні гроші). У згаданій вище справі Хедквіст проти Швеції на це звернув увагу Свропейський суд справедливості, зауваживши, що віртуальна валюта Bitcoin не має іншої мети, окрім тієї, що вона використовується для оплати і приймається з иією метою деякими операторами [19].

Таким чином, незалежно від того, чи визначені криптовалюти на законодавчому рівні в якості засобу платежу, об'єктивним $€$ той факт, що вони були створені саме з метою іх використання в якості засобу обміну та платежу, і саме так вони і використовуються, при- чому досить широко. Тобто, де-факто криптовалюти є універсальними засобами платежу, але враховуючи, що на відміну від електронних грошей, криптовалюти до офіційних грошових одиниць не прив'язані, платежі у криптовалютах не можуть вважатися грошовими, більш влучним було б їх позначення терміном «криптоплатежі».

Як уже зазначалося, в окремих країнах криптовалюти нині визнані офіційним і навіть законним засобом платежу, але не в Україні. Наявні законопроекти ставлять під сумнів визнання криптовалют засобами платежу в Україні найближчим часом, що не впливає на природу, характеристики і призначення цих об’єктів.

\section{Висновки}

Засоби платежу є досить широким класом об'єктів, об'єднаних єдиною ознакою - здатністю погашати боргові зобов'язання. У цій якості насамперед використовуються грошові кошти, але можуть використовуватися й інші об'єкти. До кола останніх належать криптовалюти, які створюються і використовуються саме в якості засобу обміну та платежу.

Враховуючи, що інститут засобів платежу не має належного опрацювання у науковій літературі як самостійного правового явища, подальші наукові розробки цього питання можуть стати важливим кроком у розумінні природи засобів платежу та об'єктів, які належать до них.

\section{Список використаних джерел:}

1. Лунц Л.А. Деньги и денежные обязательства в гражданском праве. М.: Статут, 2004. С. 350.

2. Райзберг Б.А., Лозовский Л.Ш., Стародубцева Е.Б. Современный экономический словарь. М. : ИНФРА-М, 2011. URL: http://www. consultant.ru/document/cons_doc_LAW_67315/1 a6dbaa717f8837c4bd4332121e $\overline{9} 2$ bd $\overline{7} 3$ bbec 0 49/.

3. Петрик О.М. Віддієслівні іменники опредметненої дії: структурно-морфологічний аспект. URL: www.irbis-nbuv.gov.ua/cgi-bin/ irbis nbuv/cgiirbis 64.exe? C21COM=2\&I21D $\mathrm{BN}=\overline{\mathrm{UJRN}} \& \mathrm{P} 21 \mathrm{DBN}=\mathrm{UJRN} \& I M A G E \_F I L E$ DOWNLOAD $=1 \&$ Image file_name $=$ PDF $/$ Ltkp $2008 \quad 43$ 22.pdf.

4. Bryan A. Garner - Black's Law Dictionary, 9th Edition, 2009. P. 1943.

5. Encyclopaedia Britannica. URL: https:// www.britannica.com/topic/payment.

6. Сучасний тлумачний словник української мови // За заг. ред. д-ра філолог. наук, проф. В.В. Дубічинського. Х. : ВД «Школа», 2008. C. 1008.

7. Кнаппъ Г.Ф. Очерки государственной теоріи денегъ. Одесса : Типографія Э.П. Карликъ, 1913. C. 59. 
8. Тертышный С.А. Вексель как средство платежа в нестабильной экономике России. Диссертация на соискание ученой степени кандидата экономических наук. С.-П., 2000. С. 173.

9. Сенников А. Долина теней. URL: https:// kartaslov.ru/книги/Сенников А Девять/5.

10. Везерфорд Д. История денег: борьба за деньги от песчаника до киберпространства. М. : Терра - Книжный клуб, 2001. С. 320.

11. Гладкий В. Словарь нумизмата. М. : Центрполиграф. С. 377.

12. Розанова Н.M. Монетарная экономика. Теория денег и кредита: в 2 т. Т. 1. М. : Юрайт, 2016. C. 269.

13. Цивільний кодекс України від 16 січня 2003 року № 435-IV; зі змінами. URL: https:// zakon.rada.gov.ua/laws/show/435-15.

14. Про платіжні системи та переказ коштів в Україні : Закон України від 05 квітня 2001 року № 2346-III зі змінами. URL: https://zakon.rada. gov.ua/laws/show/2346-14.

15. Про Національний банк України : Закон України від 20 травня 1999 року № 679-XIV зі змінами. URL: https://zakon.rada.gov.ua/laws/ show $679-14$

16. Щодо визначення окремих понять. Лист Національного банку України від 07.06.2013 № 25-112/6750. URL: http://zakon2. rada.gov.ua/laws/show/v6750500-13.

17. European Central Bank. Virtual currency schemes. October, 2012. URL: https:// www.ecb.europa.eu/pub/pdf/other/virtualcurrencyschemes201210en.pdf.

18. Opinion of the European Central Bank CON/2016/49 // European Central Bank 12.10.2016. URL: https://www.ecb.europa.eu/ecb/ legal/pdf/en con 201649 f sign.pdf.

19. European Court of Justice. Reports of Cases 22 October 2015 Case C-264/14. Skatteverket v David Hedqvis. [Електронний ресурс]. URL: http://eur-lex.europa.eu/legal-content/EN/TXT/ PDF/?uri=CELEX:62014CJ0264.

20. Bundesministerium der Finanzen. Betreff „Umsatzsteuerliche Behandlung von Bitcoin und anderen sog. virtuellen W hrungen; EuGH-Urteilvom 22. Oktober 2015, C-264/14, Hedqvist”. GZ III C 3-S 7160-b/13/10001; DOK 2018/0163969. 27. Februar, 2018. URL: http://www.bundesfinanzministerium. de/Content/DE/Downloads/BMF_Schreiben/ Steuerarten/Umsatzsteuer/UmsatzsteuerAnwendungserlass/2018-02-27-umsatzsteuerlichebehandlung-von-bitcoin-und-anderen-sogvirtuellen-waehrungen.pdf;jsessionid $=41 \mathrm{D}$ 281 B 5241 D 47 C 388 E F 2 F 220 B 43 C $946 ?$ $\mathrm{blob}=$ publicationFile $\& \mathrm{~V}=1$.

21. Bitcoin regulation overhaul in Japan. 01 Apr 2017. URL: https://bravenewcoin.com/ news/bitcoin-regulation-overhaul-in-japan/.

22. О развитии цифровой экономики. Декрет Президента Республики Беларусь № 8 от 21 декабря 2017 года. URL: president.gov.by/uploads/ archives/Decret-8.zip.

Serhii Chaplian. Origin of means of payment and their correlation with similar legal institutions

The article considers the means of payment as a legal institution, their origin and correlation with the means of exchange and money, defines the concept of "payment", considers such alternative non-monetary means of payment as cryptocurrencies. The publication emphasizes that the fundamental difference between exchange and payment is that in exchange the property is transferred as compensation for a certain good or something, while the payment should be considered a transfer of certain property, including money, to the obligated person for the purpose of fulfilling a debt obligation.

Based on this definition of payment, we consider to define means of payment as property (values), including, but not limited to, money transferred by the debtor in the obligation to the creditor in order to fulfill the debt obligation. The article also considers the correlation between the terms "means of exchange" and "means of payment", which may partially coincide, but such a coincidence does not result in the identification of these concepts, given the differences in their content, as means of exchange are not always accepted as means of payment.

The origin of means of exchange and payment is the result of market mechanisms, but due to the influence of the state from the plurality of means of payment there are separated a group of legal tender, which arise on the basis of regulations and guaranteed by the state to pay debts. Legal tender is intended to pay taxes and pay off obligations, even in the absence of property that has been agreed by the parties.

We also described in the publication the possibility of including to means of payment such new objects of commodity-money circulation as cryptocurrencies. Today there is no consensus to this legal phenomenon, and in many countries, including Ukraine, cryptocurrencies are not accepted as means of payment. At the same time, some countries have legally adopted cryptocurrencies as legal tender. Based on the legal nature of cryptocurrencies, we should consider cryptocurrencies as means of payment, however, since cryptocurrencies are not money at the moment, we suggest using the term "cryptopayments".

Key words: payment, means of payment, legal tender, means of exchange, money, cryptocurrencies. 